\title{
STUDIES ON THE RELATIONSHIP BETWEEN GLUCOSE OXIDATION AND INTERMEDIARY METABOLISM. I. THE INFLUENCE OF GLYCOLYSIS ON THE SYNTHESIS OF CHOLESTEROL AND FATTY ACID IN NORMAL LIVER ${ }^{1,2}$
}

\author{
By MARVIN D. SIPERSTEIN AND VIOLET M. FAGAN \\ (From the Department of Internal Medicine, The University of Texas \\ Southwestern Medical School, Dallas, Texas)
}

(Submitted for publication January 13, 1958; accepted February 20, 1958)

Since the original demonstration by Stetten and Boxer that the diabetic animal is relatively incapable of synthesizing fatty acids (2), numerous investigators have confirmed the marked dependence of fatty acid synthesis on glucose oxidation (3-5). Masoro, Chaikoff, Chernick, and Felts have shown that in the fasted as well as in the diabetic rat the production of fatty acids by the liver is sharply depressed (6). Reinstitution of carbohydrate oxidation by the administration of insulin to the diabetic animal or by the feeding of glucose alone to the fasted rat will readily restore their ability to synthesize fatty acids, while on the other hand, the administration of fat or protein at least to the latter animals has little or no such effect (6-9). These studies have strongly indicated that for "lipogenesis" 3 to proceed at an appreciable rate there exists a specific requirement for concomitant glucose breakdown. Furthermore, there is abundant evidence to demonstrate that lipogenesis is readily accelerated to abovenormal levels by excessive glucose catabolism $(6,9,10)$.

Cholesterol synthesis, too, appears to be in part controlled by the rate of glycolysis; however, this relationship is a more complicated one than that which exists between glycolysis and fatty acid synthesis. Tomkins and Chaikoff were the first to show that in the liver of the fasted rat cholesterol synthesis is greatly depressed (11). A spe-

\footnotetext{
1 A preliminary report of these studies has been previously published (1).

2 These studies were supported by grants from the American Heart Association, the Dallas Heart Association, and the National Heart Institute, United States Public Health Service.

${ }^{3}$ As is customary, "lipogenesis" is used in this and the following paper to refer to the synthesis of fatty acids; "lipid" will here refer to the two lipids under study, namely cholesterol and fatty acids.
}

cific dietary deficiency responsible for this effect was not established; however, it was demonstrated that the feeding of glucose alone was capable of restoring cholesterol synthesis to normal levels. In the diabetic animal cholesterol synthesis has been reported to be normal $(4,5)$ or at times decreased (4), and in yet another study cholesterolgenesis was found to be increased (12). The reason for these different results is not apparent, but it may be related to the relative severity of the diabetes and hence to the degree of impairment of glycolysis.

It is clear from these many lines of research, therefore, that the synthesis of both cholesterol and fatty acids is greatly influenced by the amount of glucose being oxidized within the cell; however, the mechanism by which glucose produces these effects has remained obscure.

It has been recently demonstrated that, contrary to older concepts, glucose can be broken down in

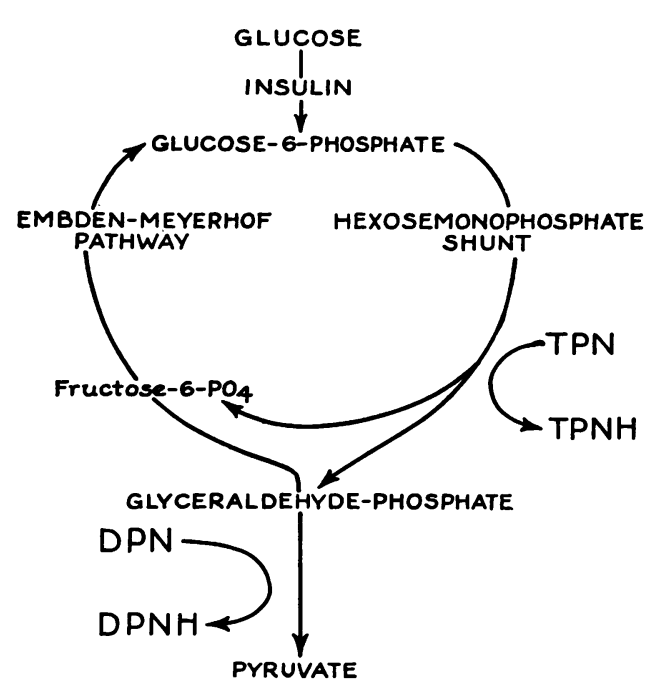

Fig. 1. Summary of the Routes of Hepatic Glycolysis 
the liver by either of two pathways (Figure 1). One is the well known Embden-Meyerhof (EM) route over which most of the glucose of the liver cell is probably oxidized; the other is the hexosemonophosphate (HMP) shunt. The quantitative importance of HMP glycolysis ${ }^{4}$ is still uncertain. The results of some studies have indicated that this pathway may account for as much as 30 to 50 per cent of hepatic glycolysis (13-15), while in other experiments the HMP route has apparently been responsible for less than 10 per cent of the glucose metabolized by the liver (14, 16-18). In spite of the fact that the HMP shunt may play a quantitatively minor role in glucose oxidation, it seemed possible that this pathway might exert an influence on the regulation of lipid synthesis out of proportion to its function in glucose metabolism. For this reason a study of the relationship between glycolysis and the synthesis of fatty acids and cholesterol has been carried out using cell-free preparations of rat liver. The relative importance of each of the two routes of glucose breakdown in the control of lipid synthesis has been evaluated by using acetate- $1-\mathrm{C}^{14}$ to determine the rates of synthesis while glucose oxidation was stimulated alternately via the EmbdenMeyerhof pathway or via the hexosemonophosphate shunt. Studies of the influence of glycolysis on lipid synthesis in normal liver are reported here. An investigation of the cause of the lipogenic defect in diabetes is described in the following paper (19).

\section{EXPERIMENTAL PROCEDURE}

Use was made in these studies of carefully homogenized, cell-free preparations of rat liver. As prepared, such systems have the advantage that they will carry out most of the reactions of the normal cell, and yet their use allows one to manipulate directly many of these metabolic processes. These preparations thus provide easily controlled models from which inferences can be drawn regarding metabolic processes in the intact cell.

The method used to investigate the function of the two pathways of glucose oxidation was suggested by the finding of Wenner, Dunn, and Weinhouse, that the addition of diphosphopyridine nucleotide (DPN) to liver homogenates markedly increases the rate of oxidation of glucose (20). This DPN-stimulated breakdown of glucose was later shown to occur primarily via Embden-

4 "Glycolysis" will be used in this paper to indicate the breakdown of glucose by either the Embden-Meyerhof pathway or the hexosemonophosphate shunt.
Meyerhof glycolysis (14). These authors have also reported a single experiment in which supplementation with both triphosphopyridine nucleotide (TPN) and DPN caused an increase in glucose oxidation which occurred predominantly by way of the HMP route (14).

Studies in our laboratory have confirmed and extended these observations (21). We have demonstrated that the addition of TPN alone to a liver homogenate markedly stimulates the oxidation of glucose over the hexosemonophosphate pathway. DPN alone, as was also indicated by Wenner's studies, enhances primarily EM glycolysis.

A means is therefore available for stimulating glucose breakdown primarily down one glycolytic pathway or the other (Figure 1). By supplementing a homogenate with either DPN or TPN and simultaneously measuring the rates of incorporation of acetate-1-C14 into both cholesterol and fatty acids, the role of each of these two pathways of glucose oxidation in controlling lipid synthesis could be studied.

Treatment of animals. Male, Long-Evans rats obtained from the Diablo Animal Laboratories, Berkeley, Calif., were used throughout this study. Their weights ranged from 150 to $250 \mathrm{Gm}$. They were maintained on Purina Laboratory Chow except for a two or three day period prior to killing when they were given ad libitum a 67 per cent glucose diet.5 Only rats that had food in their stomachs at the time of death were used in the experiments.

Preparation of homogenates and incubation procedure. Animals were stunned by a blow on the head, their throats cut, and their livers perfused through the portal vein with $15 \mathrm{ml}$. of the ice-cold phosphate buffer, $0.1 \mathrm{M}$, $\mathrm{pH}$ 7.7. The livers were then quickly excised, placed in the cold buffer and allowed to cool. In early studies ice buckets were used for this purpose; however, more uniform results were obtained if the entire procedure was carried out in a room maintained at $5^{\circ} \mathrm{C}$. The livers were weighed, placed in a Dounce homogenizer (22) and a volume of phosphate buffer equal to the weight of the liver, plus glutathione ${ }^{6}$ to make a final concentration of $10 \mu \mathrm{M}$ per $\mathrm{ml}$. were added. The livers were then homogenized with five to six slow strokes of a plunger having a clearance of about 0.5 to $1 \mathrm{~mm}$. This is looser than the "loose" plunger supplied with the commercial Dounce homogenizer. The resulting homogenate was centrifuged at $800 \times \mathrm{G}$ for 10 minutes at $-1^{\circ} \mathrm{C}$., and the supernatant containing the broken liver cells minus nuclei was used as described below.

5 The composition of the diet was as follows: glucose, 67 per cent ; casein, 25 per cent ; Hawk-Oser salt mixture, 7 per cent; vitamins per $1,000 \mathrm{Gm}$. of diet-inositol, 500 mg.; folic acid, $10 \mathrm{mg}$; $0.1 \mathrm{ml}$. oleum percomorphum containing vitamin $A, 6,000$ units and vitamin $D, 850$ units; one bottle of Folbesyn (Lederle) containing thiamine, $10 \mathrm{mg}$., riboflavin, $10 \mathrm{mg}$., sodium pantothenate, $10 \mathrm{mg}$., niacinamide, $50 \mathrm{mg}$., pyridoxine, $5 \mathrm{mg}$., B-12, 15 $\mu \mathrm{g}$., and ascorbic acid, $300 \mathrm{mg}$.

6 The omission of glutathione was found to have no detectable influence on lipogenesis. 
TABLE I

Effect of homogenate dilution on lipid synthesis *

\begin{tabular}{|c|c|c|c|}
\hline \multirow{2}{*}{$\begin{array}{l}\text { Ratio of } \\
\text { liver weight } \\
\text { to buffer } \\
\text { volume }\end{array}$} & \multicolumn{3}{|c|}{$\begin{array}{l}\text { Per cent of added acetate-1-C } \\
\text { recovered in: }\end{array}$} \\
\hline & $\begin{array}{l}\text { Fatty } \\
\text { acids }\end{array}$ & Cholesterol & $\mathrm{CO}_{2}$ \\
\hline $\begin{array}{l}1: 3.0 \\
1: 2.0 \\
1: 1.5 \\
1: 1.25 \\
1: 1.0\end{array}$ & $\begin{array}{r}1.1 \\
6.6 \\
14.3 \\
20.5 \\
35.3\end{array}$ & $\begin{array}{l}0.02 \\
0.17 \\
0.34 \\
0.36 \\
0.63\end{array}$ & $\begin{array}{l}0.6 \\
1.3 \\
3.0 \\
3.8 \\
8.3\end{array}$ \\
\hline
\end{tabular}

* Concentration of additions : glucose- 6 -phosphate, $18 \times$ $10^{-3} \mathrm{M}$; TPN, $0.7 \times 10^{-3} \mathrm{M}$; potassium acetate, $2 \times 10^{-3}$ $\mathrm{M}$ in a total volume of $1.35 \mathrm{ml}$. (Incubated for one hour at $37^{\circ} \mathrm{C}$.)

Such a homogenate represents a relatively concentrated preparation of liver tissue. It can be readily centrifuged and pipetted and provides a minimum dilution of the soluble enzymes and cofactors of the cell. This preparation will synthesize fatty acids and with added coenzymes will also synthesize cholesterol; it will often perform these functions at rates comparable to those seen in liver slices (Table I). More dilute homogenates, as also shown in Table I, were found to have less ability to carry out these processes and their use was abandoned.

All incubations were carried out in the modified Warburg flasks designed by Baruch and Chaikoff (23). Sealing such vessels with serum caps allows samples to be withdrawn or additions to be made without opening the flasks. Either 1 or $2 \mathrm{ml}$. of the homogenate was placed in the outer chamber of the flask and the substrates, ${ }^{7}$ coenzymes, ${ }^{8}$ acetate-1- $\mathrm{C}^{14} \mathbf{9}$ and water were then added as indicated in Table II to give a constant volume of either 1.4 or $2.5 \mathrm{ml}$. The flasks were next gassed with 95 per cent $\mathrm{O}_{2}, 5$ per cent $\mathrm{CO}_{2}$ for 10 seconds and incubated at $37.5^{\circ} \mathrm{C}$. in a Dubnoff shaker for one hour unless otherwise indicated.

\section{ANALYTICAL METHODS}

$\mathrm{C}^{14} \mathrm{O}_{2}$. At the end of the incubation the flasks were placed in an ice bath and $1 \mathrm{ml}$. of alkaline Hyamine $10 \mathrm{X}$ 1:1 methanol-toluene, prepared as described by Passmann, Radin, and Cooper (24), was injected through the serum cap into the center well. Two-tenths ml. of $10 \mathrm{~N}$ sulfuric acid was injected into the outer well containing the incubation mixture; the flasks were then shaken at 0 to $5^{\circ} \mathrm{C}$. for 30 minutes to allow the Hyamine to absorb the $\mathrm{C}^{14} \mathrm{O}_{2}$. It was found necessary to carry out this step

7 Glucose-6-phosphate was obtained from the Sigma Chemical Company; isocitrate was purchased from Nutritional Biochemical Inc.

8 Triphosphopyridine nucleotide and diphosphopyridine nucleotide were purchased either from the Sigma Chemical Company or the Pabst Laboratories.

${ }^{9}$ Acetate-1-C ${ }^{14}$ was prepared by Tracerlab, Inc., or the New England Nuclear Corporation. at reduced temperature in order to prevent acetic acid- $\mathrm{C}^{14}$ from being absorbed by the Hyamine solution. Trapping the $\mathrm{CO}_{2}$ at a temperature of $37^{\circ} \mathrm{C}$. resulted in as much as 1 per cent of the acetate- $\mathrm{C}^{14}$ appearing in the Hyamine in the 30 minute period.

The Hyamine- $\mathrm{C}^{14} \mathrm{O}_{2}$ solution was next transferred quantitatively with toluene into a $10 \mathrm{ml}$. volumetric flask. A $2 \mathrm{ml}$. aliquot was placed in $16 \mathrm{ml}$. of a 0.4 per cent solution of diphenyloxazole in toluene and the $\mathrm{C}^{\mathbf{1 4}}$ assayed in a Packard Liquid Scintillation Counter. ${ }^{10}$ Total $\mathrm{CO}_{2}$ was determined with the use of a Van Slyke manometric apparatus.

Cholesterol- $\mathrm{C}^{14}$ determination. The homogenate was saponified by adding 90 per cent $(w / v)$ potassium hydroxide $(1 \mathrm{ml}$. to $2.5 \mathrm{ml}$. of incubation mixture or $0.5 \mathrm{ml}$. to the $1.4 \mathrm{ml}$. mixture) and heating in an autoclave at 15 pounds pressure for one hour. The saponified homogenate was then transferred to a $250 \mathrm{ml}$. Erlenmeyer flask, and ethanol was added to give a 50 per cent solution. The nonsaponifiable material was next extracted with petroleum ether and the cholesterol fraction (which includes other $\beta$ sterols) was isolated as the digitonide by the procedure of Sperry and Webb (25). The digitonide was dissolved with heating in $2.2 \mathrm{ml}$. of methanol and $1 \mathrm{ml}$. was added to $16 \mathrm{ml}$. of the liquid scintillation solution for $\mathrm{C}^{14}$ determination.

Fatty acid-C $C^{14}$ determination. Method I: After extraction of the cholesterol the saponified homogenate was acidified, and the fatty acids were isolated by extensive extraction of the mixture with petroleum ether. The pooled extracts were concentrated, washed twice with water and made up to a $10 \mathrm{ml}$. volume. A $2 \mathrm{ml}$. aliquot of the petroleum ether extract was assayed for fatty acid- $\mathrm{C}^{14}$ as described above.

Method II: In later studies an improved rapid method for fatty acid isolation was devised. This gave clear solutions which did not cause the slight quenching of the liquid scintillator which the somewhat yellow solutions of Method I occasionally produced. After removing the nonsaponifiable material as described above, the $250 \mathrm{ml}$. Erlenmeyer flask was heated on a steam bath to remove the ethanol. Water was then added to give a volume of about 5 to $6 \mathrm{ml}$. and the mixture was acidified below $\mathrm{pH}$ 3.0 with concentrated sulfuric acid. After cooling, exactly $20 \mathrm{ml}$. of petroleum ether was added; the flask was then stoppered and shaken for 15 minutes at top speed in an International Bottle Shaker, Size 2. Approximately $5 \mathrm{ml}$. of the clear supernatant was placed in a $10 \mathrm{ml}$. glassstoppered centrifuge tube and washed twice with $5 \mathrm{ml}$. portions of water. A $2 \mathrm{ml}$. aliquot of the petroleum ether was then taken for assay of the fatty acid- $\mathrm{C}^{\mathbf{1 4}}$.

\section{RESULTS}

\section{Effect of glycolytic pathway on fatty acid synthesis}

The results of stimulation of the EmbdenMeyerhof or the hexosemonophosphate pathways

10 Packard Instrument Co., LaGrange, Ill. 
TABLE II

Influence of glycolytic pathways upon lipid synthesis in normal livers*

\begin{tabular}{|c|c|c|c|c|c|c|c|c|c|}
\hline \multirow[b]{2}{*}{$\begin{array}{l}\text { Experi- } \\
\text { ment }\end{array}$} & \multirow{2}{*}{$\begin{array}{c}\text { Glycolytic } \\
\text { pathway } \\
\text { stimulated }\end{array}$} & \multicolumn{3}{|c|}{ Acetate-1-C14 converted to: } & \multirow[b]{2}{*}{$\begin{array}{c}\text { Experi- } \\
\text { ment }\end{array}$} & \multirow{2}{*}{$\begin{array}{c}\text { Glycolytic } \\
\text { pathway } \\
\text { stimulated }\end{array}$} & \multicolumn{3}{|c|}{ Acetate-1-C ${ }^{14}$ converted to: } \\
\hline & & $\begin{array}{c}\text { Fatty } \\
\text { acid }\end{array}$ & Cholesterol & $\mathrm{CO}_{2}$ & & & $\begin{array}{l}\text { Fatty } \\
\text { acid }\end{array}$ & Cholesterol & $\mathrm{CO}_{2}$ \\
\hline & & $m \mu M$ & $m \mu M \times 10^{-2}$ & $m \mu M$ & & & $m \mu M$ & $m \mu M \times 10^{-2}$ & $m \mu M$ \\
\hline 1 & $\begin{array}{l}\text { Neither } \\
\text { HMP } \\
\text { EM } \\
\text { HMP +EM }\end{array}$ & $\begin{array}{r}7 \\
46 \\
20 \\
304\end{array}$ & $\begin{array}{r}<6 \\
374 \\
<6 \\
172\end{array}$ & $\begin{array}{l}297 \\
564 \\
114 \\
536\end{array}$ & 16 & $\begin{array}{l}\text { Neither } \\
\text { HMP } \\
\text { EM } \\
\text { HMP+EM }\end{array}$ & $\begin{array}{r}1 \\
94 \\
3 \\
65\end{array}$ & $\begin{array}{r}20 \\
161 \\
20 \\
56\end{array}$ & $\begin{array}{l}15 \\
54 \\
19 \\
41\end{array}$ \\
\hline 2 & $\begin{array}{l}\text { Neither } \\
\text { HMP } \\
\text { EM } \\
\text { HMP+EM }\end{array}$ & $\begin{array}{r}17 \\
760 \\
81 \\
2,057\end{array}$ & $\begin{array}{l}<11 \\
440 \\
<11 \\
229\end{array}$ & $\begin{array}{l}415 \\
376 \\
381 \\
246\end{array}$ & 17 & $\begin{array}{l}\text { Neither } \\
\text { HMP } \\
\text { EM } \\
\text { HMP+EM }\end{array}$ & $\begin{array}{c}0.8 \\
12 \\
2 \\
17\end{array}$ & $\begin{array}{l}15 \\
15 \\
10 \\
10\end{array}$ & $\begin{array}{r}4 \\
46 \\
15 \\
66\end{array}$ \\
\hline 3 & $\begin{array}{l}\text { Neither } \\
\text { HMP } \\
\text { EM } \\
\text { HMP +EM }\end{array}$ & $\begin{array}{r}6 \\
1,254 \\
77 \\
3,213\end{array}$ & $\begin{array}{r}<22 \\
2,982 \\
<22 \\
1,099\end{array}$ & $\begin{array}{l}336 \\
193 \\
161 \\
131\end{array}$ & 18 & $\begin{array}{l}\text { Neither } \\
\text { HMP } \\
\text { EM } \\
\text { HMP +EM }\end{array}$ & $\begin{array}{l}0.3 \\
30 \\
9 \\
20\end{array}$ & $\begin{array}{l}15 \\
87 \\
15 \\
66\end{array}$ & $\begin{array}{r}3 \\
98 \\
18\end{array}$ \\
\hline 4 & $\begin{array}{l}\text { Neither } \\
\text { HMP } \\
\text { EM } \\
\text { HMP +EM }\end{array}$ & $\begin{array}{r}2 \\
70 \\
13 \\
775\end{array}$ & $\begin{array}{r}<6 \\
1,580 \\
<6 \\
686\end{array}$ & $\begin{array}{r}11 \\
64 \\
9 \\
54\end{array}$ & 19 & $\begin{array}{l}\text { Neither } \\
\text { HMP } \\
\text { EM } \\
\text { HMP+EM }\end{array}$ & $\begin{array}{r}4 \\
31 \\
5 \\
46\end{array}$ & $\begin{array}{r}1 \\
158 \\
16 \\
91\end{array}$ & $\begin{array}{r}16 \\
164 \\
83 \\
150\end{array}$ \\
\hline 5 & $\begin{array}{l}\text { Neither } \\
\text { HMP } \\
\text { EM } \\
\text { HMP +EM }\end{array}$ & $\begin{array}{r}10 \\
723 \\
52 \\
738\end{array}$ & $\begin{array}{r}<5 \\
228 \\
<5 \\
81\end{array}$ & $\begin{array}{r}257 \\
60 \\
252 \\
99\end{array}$ & 20 & $\begin{array}{l}\text { Neither } \\
\text { HMP } \\
\text { EM } \\
\text { HMP+EM }\end{array}$ & $\begin{array}{r}2 \\
155 \\
42 \\
167\end{array}$ & $\begin{array}{r}10 \\
6,222 \\
31 \\
2,372\end{array}$ & $\begin{array}{r}15 \\
96 \\
346 \\
306\end{array}$ \\
\hline 6 & $\begin{array}{l}\text { Neither } \\
\text { HMP } \\
\text { EM } \\
\text { HMP+EM }\end{array}$ & $\begin{array}{r}4 \\
173 \\
17 \\
178\end{array}$ & $\begin{array}{r}<5 \\
3,279 \\
<5 \\
1,397\end{array}$ & $\begin{array}{l}194 \\
154 \\
210 \\
124\end{array}$ & 21 & $\begin{array}{l}\text { Neither } \\
\text { HMP } \\
\text { EM } \\
\text { HMP+EM }\end{array}$ & $\begin{array}{c}4 \\
524 \\
0.8 \\
606\end{array}$ & $\begin{array}{r}<5 \\
<5 \\
1,326\end{array}$ & $\begin{array}{l}276 \\
230 \\
257 \\
207\end{array}$ \\
\hline 7 & $\begin{array}{l}\text { Neither } \\
\text { HMP } \\
\text { EM } \\
\text { HMP+EM }\end{array}$ & $\begin{array}{c}0.3 \\
85 \\
2 \\
75\end{array}$ & $\begin{array}{r}<2 \\
179 \\
<2 \\
66\end{array}$ & $\begin{array}{r}74 \\
111 \\
130 \\
114\end{array}$ & 22 & $\begin{array}{l}\text { Neither } \\
\text { HMP } \\
\text { EM } \\
\text { HMP+EM }\end{array}$ & $\begin{array}{r}5 \\
112 \\
3 \\
260\end{array}$ & $\begin{array}{r}<5 \\
9,614 \\
31 \\
8,787\end{array}$ & $\begin{array}{l}454 \\
261 \\
357 \\
321\end{array}$ \\
\hline 8 & $\begin{array}{l}\text { Neither } \\
\text { HMP } \\
\text { EM } \\
\text { HMP+EM }\end{array}$ & $\begin{array}{r}1 \\
113 \\
8 \\
85\end{array}$ & $\begin{array}{r}10 \\
867 \\
10 \\
362\end{array}$ & $\begin{array}{r}37 \\
100 \\
96 \\
69\end{array}$ & 23 & $\begin{array}{l}\text { Neither } \\
\text { HMP } \\
\text { EM } \\
\text { HMP+EM }\end{array}$ & $\begin{array}{r}2 \\
339 \\
16 \\
275\end{array}$ & $\begin{array}{r}<5 \\
7,211 \\
15 \\
3,942\end{array}$ & $\begin{array}{r}98 \\
347 \\
363 \\
189\end{array}$ \\
\hline 9 & $\begin{array}{l}\text { Neither } \\
\text { HMP } \\
\text { EM } \\
\text { HMP+EM }\end{array}$ & $\begin{array}{c}0.6 \\
43 \\
2 \\
43\end{array}$ & $\begin{array}{r}36 \\
6,819 \\
20 \\
3,575\end{array}$ & $\begin{array}{r}14 \\
142 \\
49 \\
111\end{array}$ & 24 & $\begin{array}{l}\text { Neither } \\
\text { HMP } \\
\text { EM } \\
\text { HMP+EM }\end{array}$ & $\begin{array}{r}1 \\
111 \\
37 \\
173\end{array}$ & $\begin{array}{r}5 \\
676 \\
10 \\
343\end{array}$ & $\begin{array}{r}174 \\
140 \\
194 \\
94\end{array}$ \\
\hline 10 & $\begin{array}{l}\text { Neither } \\
\text { HMP } \\
\text { EM } \\
\text { HMP+EM }\end{array}$ & $\begin{array}{r}4 \\
196 \\
32 \\
147\end{array}$ & $\begin{array}{r}5 \\
3,881 \\
15 \\
1,392\end{array}$ & $\begin{array}{l}179 \\
144 \\
134 \\
100\end{array}$ & 25 & $\begin{array}{l}\text { Neither } \\
\text { HMP } \\
\text { EM } \\
\text { HMP+EM }\end{array}$ & $\begin{array}{r}2 \\
583 \\
19 \\
412\end{array}$ & $\begin{array}{c}0.5 \\
185 \\
3 \\
49\end{array}$ & $\begin{array}{l}235 \\
121 \\
216 \\
100\end{array}$ \\
\hline 11 & $\begin{array}{l}\text { Neither } \\
\text { HMP } \\
\text { EM } \\
\text { HMP+EM }\end{array}$ & $\begin{array}{r}0.7 \\
361 \\
9 \\
255\end{array}$ & $\begin{array}{r}<3 \\
452 \\
10 \\
99\end{array}$ & $\begin{array}{r}22 \\
112 \\
135 \\
84\end{array}$ & 26 & $\begin{array}{l}\text { Neither } \\
\text { HMP } \\
\text { EM } \\
\text { HMP+EM }\end{array}$ & $\begin{array}{r}62 \\
447 \\
26 \\
447\end{array}$ & $\begin{array}{r}<5 \\
1,452 \\
<5 \\
716\end{array}$ & $\begin{array}{l}853 \\
187 \\
910 \\
359\end{array}$ \\
\hline 12 & $\begin{array}{l}\text { Neither } \\
\text { HMP } \\
\text { EM } \\
\text { HMP+EM }\end{array}$ & $\begin{array}{c}0.5 \\
39 \\
3 \\
79\end{array}$ & $\begin{array}{r}<5 \\
61 \\
<5 \\
46\end{array}$ & $\begin{array}{r}17 \\
116 \\
101 \\
118\end{array}$ & 27 & $\begin{array}{l}\text { Neither } \\
\text { HMP } \\
\text { EM } \\
\text { HMP+EM }\end{array}$ & $\begin{array}{r}5 \\
235 \\
5 \\
372\end{array}$ & $\begin{array}{r}<3 \\
2,704 \\
5 \\
1,565\end{array}$ & $\begin{array}{l}270 \\
174 \\
276 \\
158\end{array}$ \\
\hline 13 & $\begin{array}{l}\text { Neither } \\
\text { HMP } \\
\text { EM } \\
\text { HMP+EM }\end{array}$ & $\begin{array}{c}0.8 \\
49 \\
2 \\
128\end{array}$ & $\begin{array}{l}15 \\
51 \\
20 \\
36\end{array}$ & $\begin{array}{r}3 \\
20 \\
11 \\
36\end{array}$ & 28 & $\begin{array}{l}\text { Neither } \\
\text { HMP } \\
\text { EM } \\
\text { HMP +EM }\end{array}$ & $\begin{array}{r}3 \\
242 \\
30 \\
262\end{array}$ & $\begin{array}{l}<3 \\
55 \\
<3 \\
13\end{array}$ & $\begin{array}{r}192 \\
113 \\
146 \\
90\end{array}$ \\
\hline 14 & $\begin{array}{l}\text { Neither } \\
\text { HMP } \\
\text { EM } \\
\text { HMP+EM }\end{array}$ & $\begin{array}{r}1 \\
10 \\
4 \\
41\end{array}$ & $\begin{array}{r}20 \\
76 \\
<5 \\
51\end{array}$ & $\begin{array}{r}6 \\
33 \\
79 \\
34\end{array}$ & 29 & $\begin{array}{l}\text { Neither } \\
\text { HMP } \\
\text { EM } \\
\text { HMP+EM }\end{array}$ & $\begin{array}{r}4 \\
231 \\
16 \\
247\end{array}$ & $\begin{array}{r}<3 \\
1,097 \\
10 \\
486\end{array}$ & $\begin{array}{r}186 \\
163 \\
192 \\
89\end{array}$ \\
\hline 15 & $\begin{array}{l}\text { Neither } \\
\text { HMP } \\
\text { EM } \\
\text { HMP+EM }\end{array}$ & $\begin{array}{r}1 \\
19 \\
3 \\
34\end{array}$ & $\begin{array}{r}<5 \\
50 \\
8 \\
485\end{array}$ & $\begin{array}{l}61 \\
60 \\
64 \\
63\end{array}$ & 30 & $\begin{array}{l}\text { Neither } \\
\text { HMP } \\
\text { EM } \\
\text { HMP+EM }\end{array}$ & $\begin{array}{c}0.2 \\
10 \\
0.9 \\
17\end{array}$ & $\begin{array}{r}<5 \\
82 \\
<5 \\
240\end{array}$ & $\begin{array}{l}80 \\
78 \\
87 \\
86\end{array}$ \\
\hline
\end{tabular}

* Experiments 1 through 23 contained glucose-6-phosphate, $20 \times 10^{-3} \mathrm{M} ; \mathrm{TPN}, 0.8 \times 10^{-3} \mathrm{M} ; \mathrm{DPN}, 0.8 \times 10^{-3} \mathrm{M}$ The potassium acetate concentration in Experiments 3 and 15 was $4 \times 10^{-3} \mathrm{M}$; in all others, it was $2 \times 10^{-3} \mathrm{M}$. Total volume was $2.5 \mathrm{ml}$.

Experiments 24 through 30 contained glucose-6-phosphate, $18 \times 10^{-3} \mathrm{M} ; \mathrm{TPN}, 0.7 \times 10^{-3} \mathrm{M} ; \mathrm{DPN}, 0.7 \times 10^{-3} \mathrm{M}$; potassium acetate, $2 \times 10^{-3} \mathrm{M}$. Total volume was $1.4 \mathrm{ml}$. 
by the addition of DPN or TPN, respectively, are shown in Table II. Glucose-6-phosphate was used as the glycolytic substrate in this study since it represents the first metabolite of glucose that is common to both pathways of glucose oxidation. As may be seen, the synthesis of fatty acids can be carried out in this system at small but significant rates even in the absence of added coenzymes. Stimulation of the Embden-Meyerhof pathway caused a moderate change in fatty acid synthesis which varied from a fivefold depression to a thirty-seven fold increase. On the other hand, enhancement of the HMP route consistently produced a very striking increase in the synthesis of fatty acids which amounted to at least 2 to 47 times that produced by EM stimulation. It is apparent, therefore, that in some manner stimulation of glucose oxidation via the HMP shunt has a far greater effect upon lipogenesis than does glycolysis via the EM route. Stimulation of both pathways of glucose oxidation usually produced an even greater accentuation of lipogenesis than that caused by the stimulation of either pathway alone; however, in about one-third of the experiments this effect was not observed.

\section{Effect of glycolysis on cholesterol synthesis}

A similar dependence of cholesterol synthesis on glucose oxidized over the HMP pathway is demonstrated in Table II. In homogenates, unsupplemented with cofactors, the synthesis of cholesterol often did not proceed at a detectable rate. Stimulation of the EM pathway had little or no effect on this process; however, enhancement of glucose oxidation via the HMP shunt caused a very marked increase in cholesterolgenesis in all but 1 of the 30 experiments. The process of cholesterol synthesis as well as that of fatty acid synthesis would therefore appear to be dependent upon the glucose using the TPN-dependent route of glucose oxidation.

It should be noted, however, that in all except Experiments 15 and 30, the addition of both TPN and DPN to the system caused a consistent depression of cholesterolgenesis relative to that seen when only the HMP shunt was stimulated (Table II). This finding is in contrast to the case of fatty acid synthesis where the presence of both cofactors usually produced maximal lipogenesis.

\section{Carbon dioxide-C ${ }^{14}$ production}

The production of $\mathrm{C}^{14} \mathrm{O}_{2}$ by the homogenate is no doubt an indication of the functioning of the $\mathrm{Krebs}$ cycle in this system. The amount of $\mathrm{C}^{14} \mathrm{O}_{2}$ released varied considerably from one experiment to another; however, the influence of glycolysis upon fatty acid and cholesterol synthesis described above was consistently observed despite these variations. It should be noted that frequently (14 out of 30 experiments) the amount of $\mathrm{C}^{14} \mathrm{O}_{2}$ produced was not significantly increased by the addition of either or both coenzymes and in the experiments recorded in Table III, in which total $\mathrm{C}^{12} \mathrm{O}_{2}$ plus $\mathrm{C}^{14} \mathrm{O}_{2}$ production was also measured, neither the total $\mathrm{CO}_{2}$ nor the specific activity of the $\mathrm{C}^{14} \mathrm{O}_{2}$ was stimulated by DPN or TPN.

TABLE III

Influence of triphosphopyridine nucleotide (TPN) and diphosphopyridine nucleotide (DPN) on $\mathrm{CO}_{2}$ production in normal liver *

\begin{tabular}{|c|c|c|c|c|}
\hline Experiment & Coenzyme & $\begin{array}{l}\mathrm{C}^{14} \mathrm{O}_{2} \\
\text { (\% of added } \\
\text { acetate-1-C14) }\end{array}$ & $\begin{array}{c}\text { Total } \mathrm{CO}_{2} \\
\left(\mathrm{C}^{12} \mathrm{O}_{2}+\mathrm{C}^{14} \mathrm{O}_{2}\right)\end{array}$ & $\left.\begin{array}{c}\text { Specific activity } \\
{\left[\frac{\mathrm{C}^{14} \mathrm{O}_{2}(\% \text { of acetate-C }}{14)}\right.} \\
\text { Total } \mathrm{CO}_{2}(m \mu M)\end{array}\right]$ \\
\hline 1 & $\begin{array}{l}\text { None } \\
\text { TPN } \\
\text { DPN } \\
\text { TPN + DPN }\end{array}$ & $\begin{array}{r}13.9 \\
8.3 \\
9.6 \\
7.5\end{array}$ & $\begin{array}{l}\mu M \\
244 \\
231 \\
246 \\
222\end{array}$ & $\begin{array}{l}57.0 \\
35.9 \\
39.0 \\
33.8\end{array}$ \\
\hline 2 & $\begin{array}{l}\text { None } \\
\text { TPN } \\
\text { DPN } \\
\text { TPN +DPN }\end{array}$ & $\begin{array}{l}8.8 \\
3.6 \\
7.1 \\
3.5\end{array}$ & $\begin{array}{l}232 \\
228 \\
222 \\
237\end{array}$ & $\begin{array}{l}37.9 \\
15.8 \\
32.0 \\
14.8\end{array}$ \\
\hline
\end{tabular}

* Concentration of additions: glucose-6-phosphate, $18 \times 10^{-2} \mathrm{M} ; \mathrm{TPN}, 0.7 \times 10^{-8} \mathrm{M} ; \mathrm{DPN}, 0.7 \times 10^{-8} \mathrm{M} ;$ potassium acetate, $2 \times 10^{-3} \mathrm{M}$ in a total volume of $1.35 \mathrm{ml}$. 


\section{Rate studies of lipid synthesis}

The previous experiments employed incubations carried out for a single period of time, namely 60 minutes. In order to determine whether the conclusions drawn from these single determinations were valid, a study of the rates of incorporation of acetate-1-C ${ }^{14}$ into fatty acids and cholesterol was carried out by measuring the extent of synthesis of cholesterol- $\mathrm{C}^{14}$ and fatty acid-C ${ }^{14}$ at intervals of from 0 to 90 minutes.

The slopes of curves obtained by plotting such data on linear coordinates represent the rates of synthesis of lipid-C ${ }^{14}$. As can be observed in Figure 2, at all time intervals studied, EM glycolysis exerted but little influence upon the synthesis of fatty acids. On the other hand, as indicated by the slopes of these curves, stimulation of the HMP pathway caused a marked increase in the rate of lipogenesis, and the addition of both DPN and TPN increased this rate still further. Inasmuch as the synthesis of fatty acids followed a linear curve from 15 to approximately 60 minutes, a 60 minute period of incubation was routinely used in these studies.

The rate of synthesis of cholesterol after a 15 minute period was also observed to be approximately constant up to a period of 60 minutes and again the results of such rate studies confirm those of the previous section (Figure 3). Enhancement of the EM pathway at no time interval produced a significant increase in the rate of cholesterol- $\mathrm{C}^{14}$

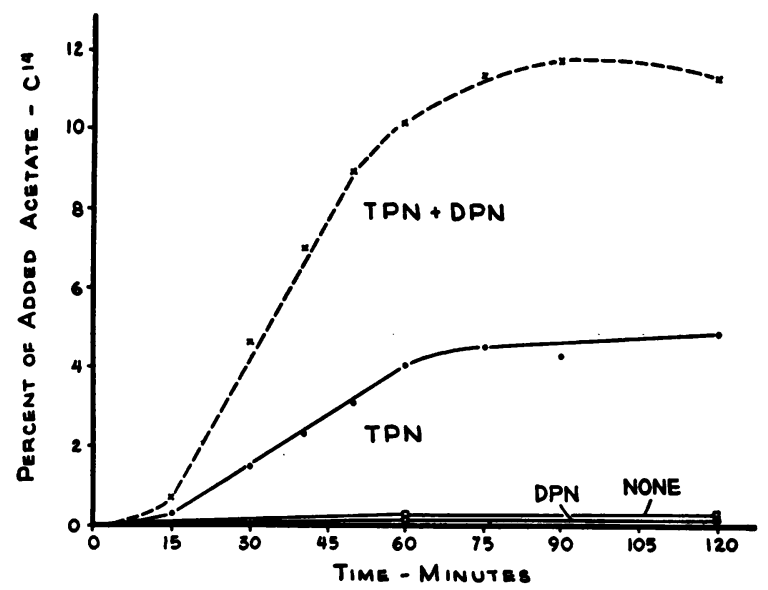

Fig. 2. The Rates of Synthesis of Fatty-Acid-C ${ }^{4}$ Conditions were as described for Experiment 1, Table II. synthesis; yet acceleration of the HMP pathway greatly increased this synthesis. Again the simultaneous stimulation of both pathways of glucose breakdown caused a decrease in the slope of the curve of cholesterol- $\mathrm{C}^{14}$ production compared to that observed when only the HMP pathway was stimulated.

\section{Mechanism of HMP stimulation of fatty acid and cholesterol synthesis}

The preceding experiments demonstrate that stimulation of the HMP shunt markedly accelerates the processes of lipogenesis and cholesterolgenesis; however, these studies leave unanswered the question as to how this pathway of glycolysis produces these striking effects.

As can be observed in Figure 1, glucose oxidized via the HMP shunt causes the production of reduced TPN (TPNH) and if the glyceraldehyde phosphate or fructose phosphate produced is converted to pyruvate, DPNH is formed as well. In contrast, glucose oxidized via the EM pathway yields only DPNH. Since TPNH is now known to be required in the synthesis of fatty acids (26) and, as we have previously suggested (27), is probably specifically required in cholesterol synthesis as well, it seemed likely that it is this cofactor, produced only by the HMP route, which mediates the effects of HMP glycolysis.

To test this possibility an alternate TPNH generating system was employed. Isocitrate and TPN will also yield TPNH, and as shown in Table IV the addition of this generating system will cause a very substantial increase in both fatty acid and cholesterol synthesis. It is therefore likely that the ability of HMP glycolysis to stimulate lipid synthesis is indeed due to the TPNH generated during glucose oxidation via this pathway. Neither isocitrate alone nor TPN alone will stimulate the synthesis of fatty acids as markedly as will both together. Cholesterol synthesis, however, was definitely stimulated by TPN in the absence of added substrate. This last result is probably due to a breakdown of endogenous glucose sufficient in the presence of supplemental TPN to yield TPNH in quantities large enough to cause the stimulation of cholesterol synthesis. The lack of a similar response in fatty acid synthesis may be explained on the basis of a greater affinity of the 
TABLE IV

Influence of reduced triphosphopyridine nucleotide (TPNH) generating systems upon fatty acid and cholesterol synthesis*

\begin{tabular}{clrr}
\hline \hline & & \multicolumn{2}{c}{$\begin{array}{c}\text { Acetate-C14 con- } \\
\text { verted to: }\end{array}$} \\
\cline { 3 - 4 } $\begin{array}{c}\text { Experi- } \\
\text { ment }\end{array}$ & Cofactor and/or substrate & $\begin{array}{c}\text { Fatty } \\
\text { acids }\end{array}$ & Cholesterol \\
\hline \multirow{3}{*}{1} & & $m \mu M$ & $m \mu M \times 10^{-2}$ \\
& None & 2 & 10 \\
& Glucose-6-phosphate & 4 & 5 \\
& Potassium isocitrate & 9 & 10 \\
& TPN +glucose-6-phosphate & 133 & 960 \\
& TPN + potassium isocitrate & 314 & 550 \\
& TPN & 17 & 190 \\
2 & Glucose-6-phosphate & 2 & 5 \\
& Sodium isocitrate & 3 & 10 \\
& TPN +glucose-6-phosphate & 96 & 764 \\
& TPN + sodium isocitrate & 370 & 114 \\
& TPN & 22 & 307 \\
& & &
\end{tabular}

* Concentration of additions: TPN, $0.8 \times 10^{-3} \mathrm{M}$; glucose-6-phosphate, $21 \times 10^{-3} \mathrm{M}$; isocitrate, $21 \times 10^{-3} \mathrm{M}$ in a total volume of $2.7 \mathrm{ml}$.

cholesterol synthesizing enzymes for the available TPNH.

It is also noteworthy that in the presence of TPN the use of glucose-6-phosphate as a substrate yielded greater amounts of cholesterol- $\mathrm{C}^{14}$ than did isocitrate. The reverse, however, was true for fatty acid synthesis; in this case isocitrate plus TPN caused a greater stimulation than did glucose-6-phosphate plus TPN.

\section{DISCUSSION}

The function of glycolysis in the economy of cellular metabolism is at present only incompletely understood. It has frequently been assumed that glucose catabolism serves mainly to supply energy in the form of ATP during the glycolytic process following which the remaining carbon substrates may be used for synthetic purposes and for the energy yielding reactions of aerobic oxidation. Evidence is now accumulating to indicate that glucose actually represents a relatively minor energy source for many tissues of the body $(28,29)$. Furthermore, the fact that only small amounts of glucose are required to produce rather profound effects in intermediary metabolism is not consistent with the concept that glycolysis acts simply as a source of nonspecific energy or of two-carbon units.

A different function for glycolysis in intermediary metabolism is suggested by the findings

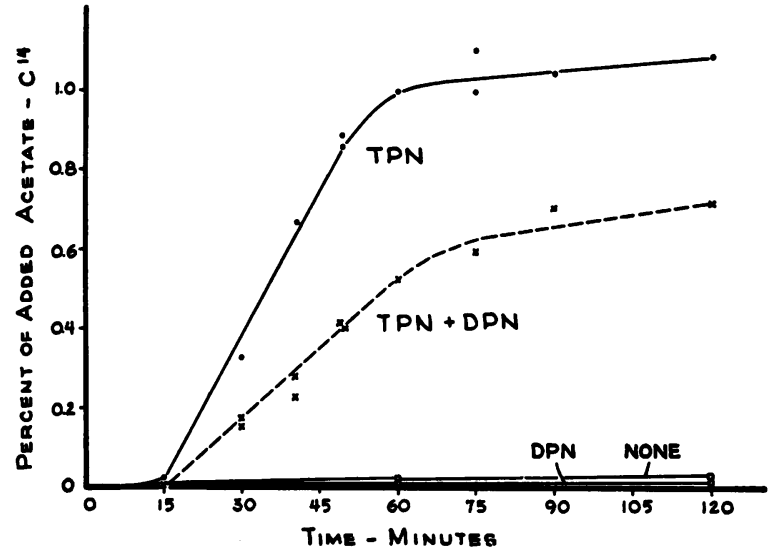

Fig. 3. The Rates of Synthesis of Cholesterol-C ${ }^{14}$ Conditions were the same as those for Experiment 1, Table II.

reported here; namely, that this phase of glucose oxidation functions at least in part as a generating system for reduced coenzymes, which by donating their protons to specific substrates in turn control various synthetic processes of the cell. In this manner the rate of glucose oxidation may serve to regulate the rates at which these various synthetic reactions occur. That such a mechanism is in part dependent upon the route by which glucose is oxidized is also suggested by the results of this study.

The specific reactions examined in the present investigation were those leading to the synthesis of fatty acids and of cholesterol. By stimulating glucose oxidation via either of the two pathways of glucose catabolism, i.e., the Embden-Meyerhof route and the hexosemonophosphate shunt, it was possible to examine the part played by each of the glycolytic pathways in regulating the synthesis of these lipids.

The rather surprising observation was made that in spite of its major role in the glycolytic process the EM pathway appears to be relatively unimportant in controlling lipid synthesis. It would follow, therefore, that the cofactors produced during the operation of this pathway, i.e., DPNH and ATP, are not limiting in the synthesis of these two lipids. In other words, though these cofactors may be required for lipid synthesis (26, $30,31)$, they are probably supplied in sufficient quantity by the normally rapid Embden-Meyerhof glycolysis of the liver cell so that a further in- 
crease in their production has little effect in stimulating lipid synthesis.

On the other hand, it would appear that the glucose which uses the hexosemonophosphate shunt has a profound influence upon the rates of synthesis of both fatty acids and cholesterol. Stimulation of this route of glucose oxidation consistently produced a very marked increase in lipid synthesis. This amounted in the case of fatty acid formation to an average of 102 times that seen in the unstimulated homogenate and in the case of cholesterol synthesis to an average increase of 293-fold.

We would suggest, therefore, that in conditions in which active glycolysis causes a stimulation of fatty acid and cholesterol synthesis this enhancement of lipid synthesis is due primarily to the relatively small portion of glucose which is oxidized via the hexosemonophosphate shunt.

These results are no doubt independent of the operation of the Krebs cycle and the TPNH thus produced since, in about one-half of the experiments shown in Table II, supplementing the system with either DPN or TPN caused no significant increase in the amount of $\mathrm{C}^{14} \mathrm{O}_{2}$ produced from the acetate- $\mathrm{C}^{14}$; nonetheless, fatty acid and cholesterol synthesis still responded as described. These findings would also indicate that the pyridine nucleotides are often present within the cell in concentrations sufficient for the reactions of the citric acid cycle to proceed at optimal rates. It is also of interest that from evidence presented in Table III, the total amount of $\mathrm{CO}_{2}$ produced $\left(\mathrm{C}^{12} \mathrm{O}_{2}\right.$ plus $\left.\mathrm{C}^{14} \mathrm{O}_{2}\right)$ need not be increased by the addition of the cofactors. In view of the fact that the oxidation of glucose to $\mathrm{CO}_{2}$ is stimulated in liver homogenates by the addition of either DPN or TPN (21), other sources of Krebs cycle intermediates must under these circumstances decrease their contribution to this cycle, thereby maintaining the total $\mathrm{CO}_{2}$ production constant.

The factor mediating the effects of glucose oxidation upon both fatty acid and cholesterol synthesis is in all probability the reduced TPN produced during the functioning of the HMP pathway, since the substitution of another TPNH generating system, isocitrate and TPN, readily replaced the hexosemonophosphate shunt in enhancing both of these syntheses (Table IV).

The probable sites of action of the reduced pyridine nucleotides in lipid synthesis are shown in Figure 4. Langdon has demonstrated that TPNH is required in the synthesis of fatty acids and that the reaction requiring this cofactor is the one involving the conversion of crotonyl-CoA to butyryl-CoA (26). Seubert, Greull, and Lynen (32) have reconstructed a fatty acid synthesizing system from liver which also requires TPNH. Brady, Mamoon, and Stadtman have shown that in the supernatant fraction of pigeon liver TPNH is a limiting cofactor for fatty acid synthesis (33); and since completion of our study, Langdon has made the same observation in normal rat liver homogenates (34). Dituri, Shaw, Warms, and Gurin, in studying liver mitochondria (35), and Hele, Popjak, and Lauryssens, using mammary gland (36), have not been able to confirm these findings and present evidence to indicate that $\mathrm{DPNH}$ is the limiting factor in fatty acid synthe-

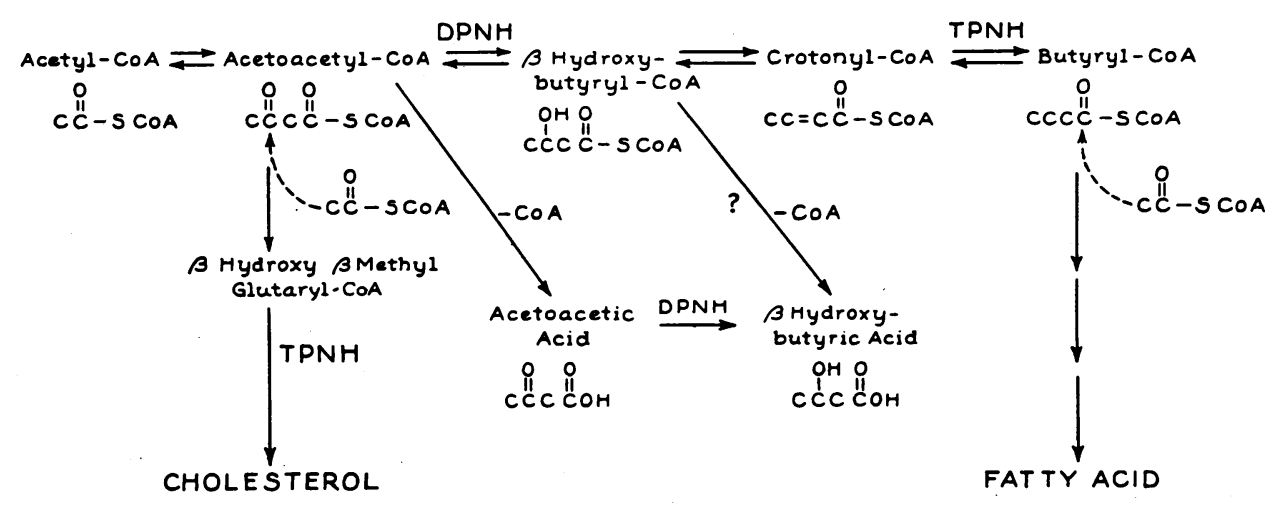

Fig. 4. Details of the Relationship Between Chölesterol and Fatty Acid Synthesis 
sis. Our results are clearly more in accord with those of Brady, Mamoon, and Stadtman and of Langdon.

The effects on lipid synthesis of simultaneous stimulation of both pathways of glycolysis are of particular interest. The addition of both TPN and DPN to the liver system was usually found to increase the rate of fatty acid synthesis above that produced by TPN alone, and it may therefore be concluded that when the HMP shunt is functioning rapidly, the rate of Embden-Meyerhof glycolysis may become a limiting factor in fatty acid synthesis. It should be noted, however, that the HMP shunt joins the EM pathway at the glyceraldehyde phosphate and fructose phosphate levels (Figure 1) and the conversion of these latter compounds to pyruvate then requires the action of DPN. It is likely, therefore, that the presence of both pyridine cofactors causes an even greater stimulation of the HMP shunt than does TPN alone. This conclusion is supported by the fact that in studies to be reported elsewhere a maximal oxidation of glucose-1- $\mathrm{C}^{14}$ was obtained under the combined influence of TPN and DPN (21).

In contrast to the observed increase in fatty acid synthesis, the stimulation of both pathways of glucose oxidation produced a consistent depression in the synthesis of cholesterol relative to that observed when only the HMP shunt was stimulated. This would suggest that in the presence of adequate glycolysis cholesterol synthesis within the cell might be regulated by the relative amounts of glucose which proceed via each of the pathways of glucose oxidation: That glucose using the HMP route would stimulate cholesterol synthesis while that traversing the EM pathway would depress this process. A possible explanation for the depressant effect of EM glycolysis upon cholesterol synthesis may be found by examining the metabolic pathways of fatty acid and cholesterol synthesis as shown in Figure 4.

The synthesis of both fatty acids and cholesterol begins with the condensation of two molecules of acetyl-coenzyme A (acetyl-CoA) to form one of acetoacetyl-CoA. This compound can then lose its CoA to form free acetoacetic acid or can be reduced by $\mathrm{DPNH}$ to yield $\beta$-hydroxybutyrylCoA. By the removal of water $\beta$-hydroxybutyrylCoA becomes crotonyl-CoA which is then reduced by TPNH to give the four-carbon, activated fatty acid, butyryl-CoA. This compound can be attacked at its fourth carbon by another molecule of acetyl-CoA; the resulting six carbon molecule can then by a series of reductions and condensations become a long chain fatty acid $(37,38)$.

If, on the other hand, the four-carbon compound attacked by the acetyl-CoA is acetoacetyl-CoA rather than butyryl-CoA, the molecule formed is $\beta$-hydroxy- $\beta$-methylglutaric acid (or its $\mathrm{CoA}$ derivative) (39), and this acid is believed to lead to the synthesis of cholesterol (40). The evidence presented here would indicate that there is a specific requirement for TPNH in the process of cholesterol synthesis. In view of this finding the requirement for DPN and ATP in the synthesis of cholesterol noted by Bucher (41) may be due to the known conversion of these two cofactors to TPN. A recent report of Tchen and Bloch (31) has indicated that the site of action of TPNH in cholesterol synthesis is at the cyclization of squalene to yield the sterol nucleus; however, TPNH did not appear to be a specific requirement since DPNH was also capable of performing this function.

In our study $\mathrm{TPNH}$ would clearly seem to be the specific factor which stimulates the synthesis of cholesterol. The relative depressant effect of DPN might then be explained as being secondary to the increase in fatty acid synthesis produced by the addition of DPN as well as TPN to the system. Such an increase in fatty acid synthesis may remove either acetoacetyl-CoA or TPNH to an extent that these compounds are no longer present in amounts capable of maintaining a rapid rate of cholesterol synthesis. The fact that EM glycolysis would appear to reduce cholesterol synthesis suggests than an in vivo method for directing glucose down this pathway at the expense of the HMP shunt might provide a means for controlling excessive cholesterol synthesis.

Finally, it is of interest that the use of isocitrate and TPN as an alternate generating system of TPNH caused an even greater enhancement of fatty acid synthesis than did glucose-6-phosphate and TPN (Table IV). On the other hand, glucose-6-phosphate proved to be a better substrate for cholesterol synthesis than did isocitrate. Since presumably both cholesterol and fatty acids are synthesized exclusively from acetyl-CoA (Figure 
4), these differences in the stimulation of lipid synthesis cannot be explained on the basis of differential dilution of separate precursor pools. One explanation for these results is that in some manner isocitrate may donate its protons via TPNH more specifically to the precursors of fatty acids while glucose-6-phosphate may more readily contribute its protons, also via TPNH, to cholesterol. This conclusion is analagous to that previously made by Hoberman based on the finding that protons from lactate are incorporated preferentially into glycogen rather than into glutamate (42).

\section{SUM MARY}

The role of glucose oxidation in the regulation of cholesterol and fatty acid synthesis has been studied in a cell-free preparation of normal rat liver. It is concluded that the stimulatory effect of glycolysis upon these syntheses is due primarily to that portion of glucose oxidation which proceeds via the hexosemonophosphate (HMP) shunt. Evidence is presented to demonstrate that it is the reduced triphosphopyridine nucleotide (TPNH) generated by the hexosemonophosphate pathway which mediates this effect of glycolysis upon both fatty acid and cholesterol synthesis. When glucose is being oxidized at a rapid rate, it would appear that the synthesis of cholesterol may be regulated by the amount of glucose using each glycolytic pathway, oxidation via the HMP route stimulating and that via the Embden-Meyerhof pathway depressing sterol synthesis.

Finally, it is suggested that the process of glucose catabolism, by donating protons to specific sites in intermediary metabolism, may serve the primary function of regulating certain synthetic processes of the cell.

\section{REFERENCES}

1. Siperstein, M. D., and Fagan, V. M. Role of glycolysis in fatty acid and cholesterol synthesis in normal and diabetic rats. Science 1957, 126, 1012.

2. Stetten, D., Jr., and Boxer, G. E. Studies in carbohydrate metabolism. III. Metabolic defects in alloxan diabetes. J. biol. Chem. 1944, 156, 271.

3. Chernick, S. S., Chaikoff, I. L., Masoro, E. J., and Isaeff, Eugenia. Lipogenesis and glucose oxidation in the liver of the alloxan-diabetic rat. J. biol. Chem. 1950, 186, 527.
4. Brady, R. O., and Gurin, S. Biosynthesis of labeled fatty acids and cholesterol in experimental diabetes. J. biol. Chem. 1950, 187, 589.

5. Van Bruggen, J. T., Yamada, P., Hutchens, T. T., and West, E. S. Lipogenesis of the intact alloxandiabetic rat. J. biol. Chem. 1954, 209, 635.

6. Masoro, E. J., Chaikoff, I. L., Chernick, S. S., and Felts, J. M. Previous nutritional state and glucose conversion to fatty acids in liver slices. J. biol. Chem. 1950, 185, 845.

7. Lyon, I., Masri, M. S., and Chaikoff, I. L. Fasting and hepatic lipogenesis from $\mathrm{C}^{14}$-acetate. J. biol. Chem. 1952, 196, 25.

8. Wyshak, G. H., and Chaikoff, I. L. Metabolic defects in the liver of fasted rats as shown by utilization of $\mathrm{C}^{14}$-labeled glucose and fructose. $\mathrm{J}$. biol. Chem. 1953, 200, 851.

9. Chernick, S. S., and Chaikoff, I. L. Insulin and hepatic utilization of glucose for lipogenesis. J. biol. Chem. 1950, 186, 535.

10. Tepperman, J., Tepperman, H. M., Wilson, M., and DeWitt, J. M. Effect of food intake on lipogenesis by liver slices in vitro. Fed. Proc. 1957, 16, 128.

11. Tomkins, G. M., and Chaikoff, I. L. Cholesterol synthesis by liver. I. Influence of fasting and of diet. J. biol. Chem. 1952, 196, 569.

12. Hotta, S., and Chaikoff, I. L. Cholesterol synthesis from acetate in the diabetic liver. J. biol. Chem. 1952, 198, 895.

13. Muntz, J. A., and Murphy, J. R. The metabolism of variously labeled glucose in rat liver in vivo. J. biol. Chem. 1957, 224, 971.

14. Wenner, C. E., and Weinhouse, S. An isotope tracer study of glucose catabolism pathways in liver. J. biol. Chem. 1956, 219, 691.

15. Bloom, B., and Stetten, D., Jr. The fraction of glucose catabolized via the glycolytic pathway. J. biol. Chem. 1955, 212, 555.

16. Katz, J., Abraham, S., Hill, R., and Chaikoff, I. L. The occurrence and mechanism of the hexose monophosphate shunt in rat liver slices. J. biol. Chem. 1955, 214, 853.

17. Agranoff, B. W., Brady, R. O., and Colodzin, M. Differential conversion of specifically labeled glucose to $\mathrm{C}^{14} \mathrm{O}_{2}$. J. biol. Chem. 1954, 211, 773.

18. Ashmore, J., Kinoshita, J. H., Nesbett, F. B., and Hastings, A. B. Studies on carbohydrate metabolism in rat liver slices. VIII. Evaluation of the Embden-Meyerhof and phosphogluconate oxidation pathways. J. biol. Chem. 1956, 220, 619.

19. Siperstein, M. D., and Fagan, V. M. Studies on the relationship between glucose oxidation and intermediary metabolism. II. The role of glucose oxidation in lipogenesis in diabetic rat liver. J. clin. Invest. 1958, 37, 1196.

20. Wenner, C. E., Dunn, D. F., and Weinhouse, S. A study of glucose oxidation in whole tissue homogenates. J. biol. Chem. 1953, 205, 409. 
21. Siperstein, M. D., and Fagan, V. M. The influence of pyridine nucleotides on the pathways of glucose oxidation. Submitted for publication.

22. Dounce, A. L., Witter, R. F., Monty, K. J., Pate, S., and Cottone, M. A. A method for isolating intact mitochondria and nuclei from the same homogenate, and the influence of mitochondrial destruction on the properties of cell nuclei. J. biophys. biochem. Cytol. 1955, 1, 139.

23. Baruch, H., and Chaikoff, I. L. A simplified method for determination of lipide- $\mathrm{C}^{\mathbf{1 4}}$ in liver. Proc. Soc. exp. Biol. (N. Y.) 1954, 86, 97.

24. Passmann, J. M., Radin, N. S., and Cooper, J. A. D. Liquid scintillation technique for measuring carbon14-dioxide activity. Analyt. Chem. 1956, 28, 484.

25. Sperry, W. M., and Webb, M. A revision of the Schoenheimer-Sperry method for cholesterol determination. J. biol. Chem. 1950, 187, 97.

26. Langdon, R. G. The requirement of triphosphopyridine nucleotide in fatty acid synthesis. J. Amer. chem. Soc. 1955, 77, 5190.

27. Siperstein, M. D. Role of glycolysis in cholesterol synthesis. Amer. J. Med. 1957, 22, 974.

28. Baker, N., Shreeve, W. W., Shipley, R. A., Incefy, G. E., and Miller, M. $C^{14}$ studies in carbohydrate metabolism. I. The oxidation of glucose in normal human subjects. J. biol. Chem. 1954, 211, 575.

29. Andres, R., Cader, G., and Zierler, K. L. The quantitatively minor role of carbohydrate in oxidative metabolism by skeletal muscle in intact man in the basal state. Measurements of oxygen and glucose uptake and carbon dioxide and lactate production in the forearm. J. clin. Invest. 1956, 35, 671.

30. Van Baalen, J., and Gurin, S. Cofactor requirements for lipogenesis. J. biol. Chem. 1953, 205, 303.

31. Tchen, T. T., and Bloch, $K$. On the conversion of squalene to lanosterol in vitro. J. biol. Chem. 1957, 226, 921.
32. Seubert, W., Greull, G., and Lynen, F. Die synthese der fettsäuren mit gereinigten enzymen des fettsäurecyclus. Angewandte Chem. 1957, 69, 359.

33. Brady, R. O., Mamoon, A. M., and Stadtman, E. R. The effects of citrate and coenzyme A on fatty acid metabolism. J. biol. Chem. 1956, 222, 795.

34. Langdon, R. G. The biosynthesis of fatty acids in rat liver. J. biol. Chem. 1957, 226, 615.

35. Dituri, F., Shaw, W. N., Warms, J. V. B., and Gurin, S. Lipogenesis in particle-free extracts of rat liver. I. Substrates and cofactor requirements. J. biol. Chem. 1957, 226, 407.

36. Hele, P., Popjak, G., and Lauryssens, M. Biosynthesis of fatty acids in cell-free preparations. 4. Synthesis of fatty acids from acetate by a partially purified enzyme system from rabbit mammary gland. Biochem. J. 1957, 65, 348.

37. Lynen, F. Functional group of coenzyme A and its metabolic relations, especially in the fatty acid cycle. Fed. Proc. 1953, 12, 683.

38. Green, D. E. Oxidation and synthesis of fatty acids in soluble enzyme systems of animal tissues. Clin. Chem. 1955, 1, 53.

39. Rabinowitz, J. L., and Gurin, S. Biosynthesis of cholesterol and $\beta$-hydroxy- $\beta$-methylglutaric acid by extracts of liver. J. biol. Chem. 1954, 208, 307.

40. Dituri, F., Cobey, F. A., Warms, J. V. B., and Gurin, $\mathrm{S}$. Terpenoid intermediates in the biosynthesis of cholesterol. J. biol. Chem. 1956, 221, 181.

41. Bucher, N. L. R. The formation of radioactive cholesterol and fatty acids from $\mathrm{C}^{14}$-labeled acetate by rat liver homogenates. J. Amer. chem. Soc. 1953, 75, 498.

42. Hoberman, H. D. Utilization of hydrogen of substrates of pyridine-nucleotide-linked dehydrogenases in reductive biosyntheses. Fed. Proc. 1957, 16, 197. 